Journal of Law \& Social Studies (JLSS)

Volume 2, Issue 2, pp 73-77, 2020

www.advancelrf.org

\title{
Ancient Dispute Resolution through Informal Processes: ADR
}

\author{
Dr. Abida Hassan \\ Corresponding author \\ Ph. D Scholar \\ University of South Asia Lahore \\ Email: abida.hassan@usa.edu.pk \\ Doctor.abidahassan@gmail.com \\ Dr. Dil Muhammad Malik \\ Dean, Department of Law \\ University of South Asia Lahore \\ Email: dilmohammad@hotmail.com
}

\begin{abstract}
The research article discusses the historical study for settlement of disputes under the umbrella of legal systems (formal and informal) prevailing in different civilizations and in various times. This research is briefly discussing the historical aspects of various legal systems in ancient times. This research highlights that human civilizations promoted both methods, but the most popular method was informal dispute resolution (ADR) in all over the world which still is needed and being popular day by day. From study, it has been founded that informal dispute resolution (ADR) has been the choice of people and they preferred to opt this process rather to go for litigation. The research has shown the benefits and importance of settlement of disputes through informal justice system. The study high lights that the system has been working very successfully in ancient times, therefore, this pre-tested process i.e., informal dispute resolution is more sustainable in any form than the formal system because it reflects amicable practices.
\end{abstract}

Key Words: Informal, Dispute Resolution, Settlement, Ancient, ADR

\section{Introduction}

Dispute resolution through informal processes (ADR), signifies the mechanisms for settling their disputes or conflicts without adopting through the procedures or processes which are required by law. However, the purpose can be obtained through different acknowledged and known methods but the settlement through private process or public interference is most important and has a special importance because of its deep roots in history and the opposite parties give their consent for settling their disagreements in a peaceful way. It may be secluded or appended with court, mandatory or intentional, prescribed or unofficial (Hornle. J 2009), same thinking depicted from the study of research work of Professor Jean R. Sternlight (2014). California Task Force also suggested to use the appropriate and suitable methods to resolve disputes arising between parties (Gumbiner, 2000).

During the pre-civilized days human beings lived a nomadic life. Domestication of animals and planets had to agriculture and human settlements. In other parts, the nomadic life continued. Disputes among human beings are as old as human beings themselves. Disputes among human beings are as old as human beings themselves. The first generation of Adam had a serious dispute which resulted the murder of Habeel (Abel). Accordingly, dispute resolution has deep roots in the development of human civilization.

The dispute resolution developed on two different patterns among the nomadic people continued with the customary methods of dispute resolution through the elders of the tribe, which the settled tribes developed on different times. During the early periods of agricultural settlements, it appears that the dispute resolution through elders continued. But with emergence of centralized administration of the strong kings such as a more formal method through courts 
encouraged. It appears that in the beginning both the systems continued. Thus, for example in Egypt, the judicial system was based on the combination of both these systems. Civil disputes, particularly partly methods work decided by the council of elders at rural level. More serious disputes, murders etc were decided by kings and later on by his vazir. This forum also had the jurisdiction to hear appeals against the decisions of village council.

The nomads continued with the customary methods of dispute resolution through the elders of the tribe, while the settled tribes developed on different lines. It appears that the dispute resolution through elders continued during the early periods of agricultural settlements, but with emergence of centralized administration of the strong kings such as Pharaohs in Egypt, a more formal method through courts emerged. It is logical to assume that both the systems continued on parallel lines in the beginning. Thus, for example, the judicial system was based on the combination of both these systems in Egypt. The civil disputes, particularly, petty matters work decided by the council of elders at rural level and more serious disputes relating to murders were decided by kings and later on by his Vizier, who also had the jurisdiction to hear appeals against the decisions of village councils.

The Greeks also adopted this dichotomy of dispute resolution by merging the formal and informal dispute resolution methods in their system, which provided for the dispute resolution through court, presided by an official judge who was assisted by a large jury of citizens. And, we find this system in some present-day common-law systems.

It is not a coincidence that formal dispute resolution (court litigation) developed after the emergence of writing, because formal court procedure can't work without written laws. Accordingly, the formal judicial system, needing writing down the decisions, developed in oldest civilizations, during the times when writing had been developed by them.

The oldest discovered written law, which prescribed certain offences, empowered the courts to decide the cases arising under that Code (Ur Nammu Code, 2300 BC). Thus, it can be safely assumed that disputes, not arising under the code, were decided by non-judicial forums. In latter periods, the Greeks adopted this dichotomy of dispute resolution by merging the formal and informal dispute resolution methods in their system, which provided for the dispute resolution through court, presided by an official judge who was assisted by a large jury of citizens. And, we find this system in some common law systems.

It has been traced that informal dispute resolution (ADR) exists from ancient times to modern times. It emerges from his work that human civilization has moved from informal (non-judicial) to formal (judicial) methods of dispute resolution and back to informal (Jerome. T Barret et. al 2009).

As mentioned earlier, disputes and settlement of disputes in the life of human being have been a major factor, informal dispute resolution replaces the formal dispute resolution process (court system), sometimes, it establishes the power which exists between the parties (Sourd in, T, 2008). Informal Dispute Resolution (ADR) denotes instruments of resolving disagreements without passing through the routes prescribed by law. Although, the aim can be achieved via several recognized and unofficial methods but the resolution through public involvement has a special significance due to its roots in history and the rival party's assent to it for finding a peaceful arrangement. It may be secluded or appended with court, mandatory or intentional, prescribed or unofficial (Hörnle J. 2009).

Informal dispute resolution (ADR) is reluctant, and the members from the legal profession will have to admit the importance of informal dispute resolution system (ADR) along with the legal system (MacFar 1 ane, J., 2008). Informal dispute resolution system (ADR) is more popular due to flexible, inexpensive, speedy and effective process, it reveals power and strength of parties (King, M. 2009). Benefits of this system can be summarized as low cost, avoidance of delay, secrecy element remains intact, confidential proceedings, non-adversarial process and elasticity. It has bestowed a new authority rather a legal requirement to support reaching of settlements at the phase prior to trial (Gould, Nicholas 2012).

\section{Materials and Methods}

Research Methodology is descriptive in nature which highlights and explains the history of ancient dispute resolution process through informal dispute resolution system (ADR) but it needs a proper attention to justify its scope and importance. The main focus of research is to discuss the most important old civilizations. The main reason for this methodology is that quantitative method could not be used because such an attempt would have involved sophisticated and expensive logistic set up.

\section{Ancient Dispute Resolution}


Informal dispute resolution has special significance in Abrahamic period. It is not easy to find the exact and clear information regarding history of Amicable Settlement of disputes through informal dispute resolution system (ADR) to resolve the disputes. But it is imaginable to determine its history since human society at the time when no courts were in existence to resolve the disputes. Different scholars have given the history of informal dispute resolution system (ADR) methods in different ways through their work.

The timeline given therein shows that Egyptians, Syrians, Phoenicians, Greeks and Chinese used informal methods of dispute resolution in ancient times (Jerome. T Barret et. al 2009). The Indus Valley Civilization relied on Panchayat (village council of elders) system since 500 BC. In Egyptian mythology, disputes between Osiris and Seth, and Horus and Seth were decided through arbitration. A mortal arbiter, Paris, decided between immortal parties i.e. Hera, Athene and Aphrodite in Greek mythology. In 350 BC, Plato also identified that action be brought in the ancestral courts in the parties fail to perform their contract and unable to resolve it before arbitrators. Cicero, a Master of Legal System in Rome observed new arbitration as part of highly developed legal system.

\subsection{Nomadic Period}

This is the period when people lived in caves or they were living a life of stone age which is called or known the Paleolithhic (Old Stone Age). Presumably 190,000 years of human existence and the period of Ice Age (Old Age or Stone Age) ended in 10,000 BCE. During the pre-civilized days, human beings lived a nomadic life, they were not living in a structured houses and neither they had permanent addresses because due to domestication of animals and plants which lead to agriculture human beings moved from place to place but they settlements continued in ancient times. There were some people who established their residences which can be called as semi-permanent residences (internet source).

Nomadic people relied on opinions and trusted to settle their disputes or matters through involvement of elders. So, the dispute resolution developed two different patterns among the nomadic and settled people. The nomads continued with the customary methods of dispute resolution through the elders of the tribe, while the settled tribes developed on different and more formal method through official forum (court) presided by an official adjudicator (judge). It appears that the dispute resolution through elders continued during the early periods of agricultural settlements, but with emergence of centralized administration of the strong kings such as Pharaohs in Egypt, a more formal method through courts emerged. It is logical to assume that both the systems continued parallel lines in the beginning. Thus, for example, the judicial system was based on the combination of both these systems in Egypt. The civil disputes, particularly, petty matters work decided by the council of elders at rural level and More serious disputes relating to murders were decided by kings and later by his wazir, who also had the jurisdiction to hear appeals against the decisions of village councils.

\subsection{Vedic Period}

The study of the Hindu law prevailing in the ancient India is very useful. In villages, Panchayat was one of the natural ways for the ancient Hindus to decide the disputes without intervention of courts. In some cases, the Panchayats mostly looked like the courts which was established by the king. The period from $300 \mathrm{BC}$ to $500 \mathrm{BC}$. is the period when Rigveda, the oldest literary work, was composed. The Aryans used to live in villages during this age. There were two popular institutions (Sabha \& Samiti). The Sabha enjoyed inter alia, certain judicial functions and acted as the National Judiciary. In addition to these two institutions there were other institutions such as Vidhata Assembly associated with civil, military and criminal matters. The system of Arbitration was probably known to the people of the early Vedic age. The arbitrator/mediator of disputes was called Madyamasi. The king participated more actively in the administration of justice and king decided civil cases himself with the help of his assistants. Sometimes, the king delegated his power to the Adhyaksha. There were also references of cases which were referred to the tribes for adjudication. At the village level, petty cases were decided by Gramyavadin. The disputes regarding boundaries of property were settled by these Sabhas and Sabha patiacting as judge.

\subsection{Dharmashastras Period}

In ancient times, Dharmashastras, the law books of Hindus were taken as sacred books for resolution of disputes. The famous textbooks were sutras of Apastamba, Gautama, Baudhayana and Vasistha. Later on, some text books took place of these law bokks which are Manusmiriti, Yajnavalkyasmriti, Naradasmriti, Visnusmriti etc., The most systematic work from these books is founded in Yajnavalkyasmriti which categorized the bokk into three parts and each part was placed at its proper and suitable portion with famous and known commentaries which could be founded in Manu-Smriti. 
The era of Dharmashastras, Manu-Smriti, Yajnavalkya, Smriti and Narada Smriti provide very important information relating to the dispute resolution institutions at that time. The period of Dharmashastras is ninth century AD. The Dharamshastra of Yajnavalkya states three types of courts sreni, Puga and Kula. These courts tried only civil cases, and appeals against these courts were challenged to the courts of judges who were appointed by the king.

The Sutras were the manuals of instructions and one of the Sutra literatures, the Dharma Sutras refer to customary law and practice. The Dharma Sutras are assigned to the period from 200 BC to 600 BC The Magadha dynasty almost overlapped with the Sutras age. There were Parishads and their decisions on the interpretations of the manuscripts were mandatory. Besides the central assembly at the capital, there were local Parishads in all the important places in the states.

Ramayana and Mahabharata, two great epics were written during this period. The epic age is estimated around 500 BC. and $200 \mathrm{BC}$. during the period of epics, there were large number of states in India. The ordinary form of government was the Kingship but there were also republics. The Sabhas, popular courts continued to flourish in the Epic age too because their decisions were usually upheld by the kings. The system of arbitration seems to have been popular in this period.

\subsection{Medieval Era}

Medieval era is a period when Muslims ruled India starting from the Arab conquest of Sindh in 712 ADs to the death of Bahadur Shah in 1857 (P. Spear, 1990). Medieval India witnessed different judicial administrations by different rulers in different times. All the Muslims in India were governed by the Islamic laws. During the Muslim rule, with respect to transactions between Muslims and non-Muslims, a mix system of arbitration laws was developed. The Hedaya contains provisions for tahkeem (arbitration) between the parties. According to it, a Hakim (an arbitrator) was required to possess the qualities essential for a Qazi, if parties to a dispute appointed an arbitrator and expressed their desire to abide by his award, he ensured the arbitration and any one of the disputants could retract before the award was made. That would be the end of the arbitration. But, in the absence of such retraction, the arbitrator would proceed to hear the arbitration and make the award. The award so made was binding on the parties who appointed arbitrator, except when the decision was not valid. But once the parties acknowledge an arbitral award, they could not afterwards retract from it. Any award passed in favor of a parent, child or wife was void ab initio. Though the Arabic language had the sanctity of a religious language of Muslims but the court language throughout the Muslim era was Persian. The king was the fountain head of justice and decided the most important cases personally. The Sultan was assisted in judicial administration by the Chief Sardar and the Chief Qazi. In the provinces, the Governor and the Qazi decided the cases. In the villages, the Panchayats exercised judicial functions (A. Zahoor).

\subsection{Marathas Period}

The judicial administration under the Marathas was not so much well organized and up to date, no codified law, no set procedure for trail of cases. The emphasis was on informal dispute resolution only and the highest court was the court of the king known as 'Hazir Majlis'. The Court also heard appeals against the decisions of the lower Courts long with trial cases and next to this court was Nyayadhish or Chief Justice who used to entertain both civil as well as criminal cases. The Village panchayat was the main instrument of civil justice which were popularly called 'PanchParmeshwar' and the Panchas were often addressed as Ma-Bap. The decision of the Panchayat was binding on the parties. An appeal from the decision of the village Panchayat laid to the Mamlatdar could assemble a Panchayat outside the village of disputants. In such suits the Panchayat's decision was subject to an appeal to the Peshwa i.e. Prime Minister. The decisions of the Panchayts were known as Panchets. A Panchet was obeyed without any protest because it was regarded as the voice of Almighty. However, Panchets were subjects to revision; decision of Kula can be revised by Srni and decisions of Sreni could be revised by the Puga and the decision of Puga was to be revised by the king or the ultimate authority or arbitrator (P.V. Kane 2015).

\section{Conclusion}

From the study, it is essential to discuss on points which will be helpful to understand and broaden the importance of human being and from whole discussion it is noted that informal dispute resolution (ADR) have been very much popular in the world even in ancient times. The outcome of this system was same as it is in the present times i.e. it is still an important choice of the people.

There is certain code of conduct which can be adopted according to the requirement of any society and allowed by law and customs. This is not necessary to provoke any society to follow the coded laws of state but the people can be 
put at freedom to adopt the suitable and convenient channel for settling their disputes among themselves or by adopting some other way which can be informal or semi-formal and semi informal or the involvement of some third person. The otion may be of people but remaining within limits as prescribed by any society and without violating the rights of any person.

In nutshell, the study of dispute resolution through informal processes indicates that the human civilization has used both processes (Formal and informal dispute resolution), which worked side by side in all the times but informal disputes resolution has been much popular than the other due to the reason that informal dispute resolution not only reduces the burden of the courts but also restore the friendly relationship of disputants to sit in future peacefully. Dispute resolution through Informal process is popular (Sourd, 2008) due to speedy, inexpensive, friendly and more effective as compared to court litigation/ formal dispute resolution process (King, M. et.al, 2009), and it is also important for legal practitioners to follow this pre-tested and successful system and to make efforts for applying this system by creating awareness among the people.

\section{References}

Ur Nammu Code, 2300 BC.

Jerome T Barret and Joseph P Barrett, A history of ADR: the story of political, Social and Cultural Movement. Association for Conflict Resolution, $1^{\text {st }}$ edition. http://www.adr.gov/events/2009/may7-2009materials-history.pdf

Sourd in, T, Alternative Dispute Resolution, Thomson Reuters, 2008, 13 \& King, M. Freiberg, A., Batagol, B. and Hyams, R., Non-Adversarial Justice, The Federation Press, 2009 at 88.

King, M., Freiberg, A, Batagol, B., and Hyams, R., Non-Adversarial Justice, The federation press, 2009 at $90-94$.

Hörnle J. (2009) Cross-border Internet Dispute Resolution. UK: Cambridge University Press, $1^{\text {st }}$ Edition, P. 48.

MacFar 1 ane, J., The New Lawyer: How Settlements Transforming the Practice of Law, UBC Press, 2008 at $10-12$.

French, Brendan 'Dispute Resolution in Australia-The Movement from Litigation to Mediation' (2007) 18 Alternative Dispute Resolution Journal, p. 214

King, M., Freiberg, A., Batagol, B., and Hyams, R., Non-Adversarial Justice, The Federation Press, 2009, p. 91, 94.

Gould, Nicholas (Fenwick Elliott LLP), Conflict avoidance and dispute resolution in construction, RICS guidance note, $1^{\text {st }}$ edition, 2012, p. 7.

Jerome T Barret and Joseph P Barrett, A history of ADR: the story of political, Social and Cultural Movement. Association for Conflict Resolution, $1^{\text {st }}$ edition. http://www.adr.gov/events/2009/may7-2009materials-history.pdf

Dr. Priyanath Sen, 'The General Principles of Hindu Jurisprudence.

P.V. Kane's 'History of Dharmashastras' (Vols.5) Volume 3. 